\title{
Coastal Habitat Mapping Along the Tanzania/Mozambique Transboundary Area Using Landsat 5 TM Imagery
}

\author{
M.A. Ferreira ${ }^{1}$, F. Andrade ${ }^{2}$, P. Cardoso ${ }^{3}$ and J. Paula ${ }^{2}$ \\ ${ }^{l}$ Instituto do Mar, Laboratório Marítimo da Guia, Av. $N^{a} .{ }^{a} r^{a}$. do Cabo, 939, 2750-374 Cascais, Portugal; \\ ${ }^{2}$ Faculdade de Ciências da Universidade de Lisboa - Centro de Oceanografia, Laboratório Marítimo da Guia, \\ Av. $N^{a}$.Sr ${ }^{a}$.do Cabo, 939, 2750-374 Cascais, Portugal; ${ }^{3}$ Strix, Lda. Tagus Space Ed. Galileu 1B 2740-278 \\ Porto Salvo, Portugal
}

\begin{abstract}
Keywords: Remote-sensing, satellite imagery, classification accuracy, tropical coastal habitats, transboundary, Mozambique, Tanzania
\end{abstract}

\begin{abstract}
Landsat 5 TM imagery was used to study the distribution of coastal habitats along the Eastern African coast, from Mnazi Bay (Tanzania) south to Pemba Bay (Mozambique), across the mouth of the Ruvuma estuary and the Quirimbas archipelago. Eight classes of coastal habitats, adapted from the Ramsar convention classification -intertidal, and subtidal -were mapped at a coarse descriptive resolution using an unsupervised classification procedure. Results for 1995 and 2005 are presented, for the entire coastline, and in detail, for the areas of the Ruvuma estuary, Palma, Mocímboa da Praia, and Ibo Island. Results were evaluated using data from ground truthing excursions during 2006. For each date, over $3,300 \mathrm{~km}^{2}$ of coastal habitats were classified. The classes with the largest coverage were "permanent shallow marine water" $\left(>1,500 \mathrm{~km}^{2}\right)$, followed by "intertidal flats" $\left(>650 \mathrm{~km}^{2}\right)$, "mangroves", and "coral reefs" (covering $>320 \mathrm{~km}^{2}$ each). Estimated overall thematic accuracy for 2005 exceeded $70 \%$.

The paper discusses a number of aspects that may influence the accuracy of the final classification and limit time-change analysis to a few of the habitats considered. The resulting spatially referenced thematic maps constitute a useful tool to aide management actions along this coast and are a valuable reference point for conservation and research planning.
\end{abstract}

\section{INTRODUCTION}

The Eastern African coast is home to a diversity of tropical and subtropical species and habitats and a growing human population, presently over 22 million (WWF, 2002). In 1998, in the framework of WWF's Ecoregion Programme (Global 200), the Eastern African Marine Ecoregion (EAME) was created, extending for approximately 4,600 $\mathrm{km}$ of coastline and including “...some or all of the territorial waters of Somalia (approx. $300 \mathrm{~km}$ ), the entire coastlines of Kenya $(500 \mathrm{~km})$, Tanzania $(900 \mathrm{~km})$, and Mozambique $(2,800 \mathrm{~km})$, and the north-eastern portion of South Africa (approx. $100 \mathrm{~km}) . "(W W F, 2002)$. Within the ecoregion, a total of 21 sites were identified, eight of which were considered to be of global importance. One of these sites is the Mtwara-Quirimbas Complex, from Mnazi Bay (Tanzania) through the Ruvuma delta (Tanzania/Mozambique border), and the Quirimbas reefs, south to Pemba Bay (Mozambique). This site is located where the South Equatorial Current meets the African coast and harbours some of the most impressive coral reefs of the Western Indian Ocean (high coral diversity, with over 50 genera) dispersed over a complex of coastal islands significantly affected by recent coral bleaching events, as well as periodic dynamite fishing in Tanzania. It is also an important nursery and feeding area for turtles, birds, and whales (Transmap, 2004; WWF, 2002). 
Within this site, two parks have been established, viz. the $650 \mathrm{~km}^{2}$ Mnazi Bay - Ruvuma Estuary Marine Park (MBREMP) created in 1999-2000 on the coast of Tanzania (IUCN, 2005) and the $7,500 \mathrm{~km}^{2}$ Quirimbas National Park, established in 2002 by the Government of Mozambique in the framework of WWF's "Gift to the Earth" program. This park encompasses a $1,500 \mathrm{~km}^{2}$ marine area with a $100 \mathrm{~km}$ coastline, including eleven islands of the Quirimbas archipelago (WWF, 2002).

In 2004, a consortium of European and African research institutions launched the TRANSMAP project (Transboundary Networks of Marine Protected Areas for integrated conservation and sustainable development: biophysical, socioeconomic and governance assessments in East Africa), aimed at developing a scientific basis for the creation of transboundary networks of Marine Protected Areas (MPAs) along the coast of East Africa (TRANSMAP, 2004). Two of the project's main goals were the definition of a baseline, through the assessment and synthesis of existing knowledge in order to identify gaps and avoid duplication, and a biophysical assessment "...to obtain the fundamental biophysical data required to identify specific habitats, particularly those supporting vulnerable species, in order to determine their current condition, restoration needs, conservation value and ecological connectedness." (ibid.)

An assessment of existing information on the distribution of coastal habitats throughout the study area was carried out. Despite the existence of a vast bibliography related to the study of various aspects of tropical coastal ecosystems and the management of coastal areas along the East African Coast, from Kenya to Mozambique, few studies present data linked to geographic information. Those that do, constitute mainly sectoral studies, referring separately to the distribution of mangroves (e.g. Spalding et al., 1997; Taylor et al., 2003; Wang et al., 2003), coral reefs (e.g. Obura et al., 2002; Obura et al., 2004; Spalding et al., 2001), or seagrasses (e.g. Bandeira and Gell, 2003; Dahdouh-Guebas et al., 1999; Ochieng and Erftemeijer, 2003), or are geographically restricted to very specific locations such as the MBREMP (e.g. Gawler and Muhando, 2004). On the other hand, the scale of most of these studies (many of them at the base of the interactive sectoral habitat maps available on-line at the United Nations Environment Programme World Conservation Monitoring Centre webpage: $\mathrm{http} / /$ www.unep-wcmc.org/) is incompatible with the objectives of the present study. In fact, their scales, often covering the entire coastlines of one or two countries, albeit useful for the quantification of habitat areas at a regional level, render them inappropriate to serve as base maps in a more detailed study. Therefore, a first approximation to the distribution and extent of major coastal habitats was necessary.

There is no single best possible approach for coastal habitat discrimination and mapping (Edwards, 2000; Seto and Fragkias, 2007). Some of the variables to consider when determining the appropriate methodology are: i) desired end product; ii) extent of the study area; iii) accuracy; iv) time; v) cost; vi) logistics related to field work/ ground truthing (e.g. accessibility). Remote sensing was used here as it constitutes a cost-effective approach for the synoptic sampling and mapping of resources of large areas over time, for land planning and monitoring purposes (Dahdouh-Guebas, 2002; Giri et al., 2008; Mumby and Edwards, 2000; Mumby et al., 2000; Thu and Populus, 2007). Given the dimension of the study area, and the objectives and deadlines of the project, as well as logistic and financial constraints, an approach based on large-scale satellite imagery was selected. Landsat Thematic Mapper (TM) (7 bands, with a spatial resolution of $30 \times 30 \mathrm{~m}^{2}$ ) was chosen because it has been reported to give best results in terms of cost-effectiveness for mapping coastal habitats at a level of coarse descriptive resolution, where only a few classes can be distinguished (Green et al., 2000; Mumby et al., 1997, 1999). This approach was preferred over a finer, but necessarily more error-prone, definition of habitats.

This paper describes the mapping of major coastal habitats undertaken in the framework of Transmap project Work Package 2 - Mapping habitat types and current uses, for the coast covered by the "Mtwara-Quirimbas Complex" site of global importance, in the Tanzania/Mozambique transboundary area, from Mnazi bay, Tanzania, on through the Quirimbas archipelago, and down to Pemba Bay, Mozambique, along c. $350 \mathrm{~km}$ of coastline (Figure 1). 

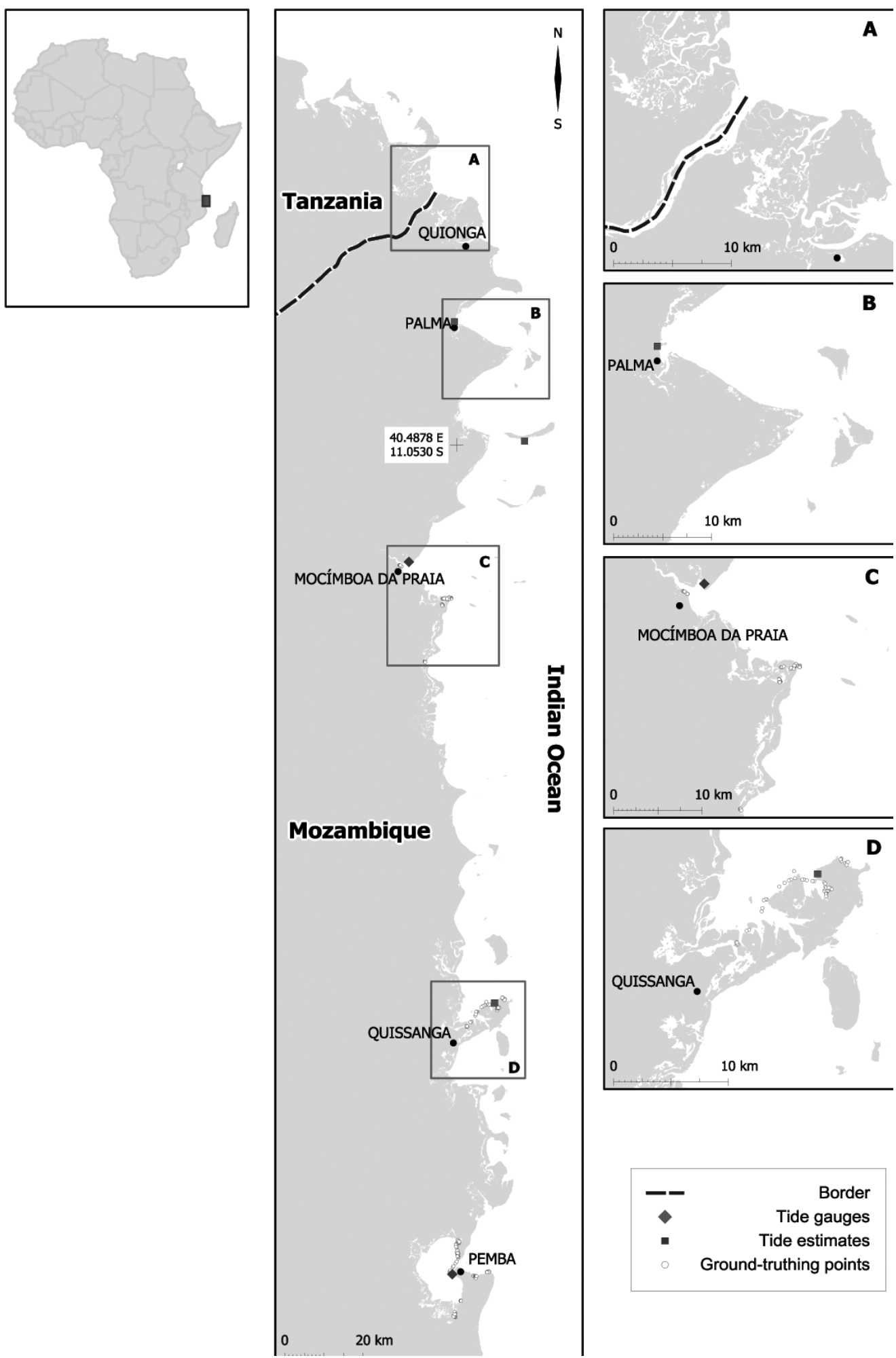

Fig. 1. Study area on the East-African coast, from Mnazi Bay (Tanzania) to Pemba Bay (Mozambique) with the location of the tide gauges used for the calculation of tide levels and the distribution of ground control points 
Images from 1995 and 2005 were classified and the results compared in order to try and understand the effect of time on the analysis since change in the corresponding coastal habitats mapping can arise both from actual change in habitat distribution, and from other sources, including tide level and range, or weather conditions.

\section{METHODS}

Coastal habitats along the Tanzania/Mozambique transboundary area (from Mnazi Bay in Tanzania, to Pemba Bay in Mozambique) were mapped using Landsat 5 TM imagery (for technical information relating to the sensor, cf.http://eros.usgs.gov/guides/ landsat_tm.html). Low cloud coverage L1G scenes were selected for anniversary dates, for April-July 1995 and April-June 2005 (Table 1). Landsat 5 scenes were provided with radiometric and geometric correction (map oriented). Subsequent image geo-correction and co-registration to known ground control points (GCP's) was applied, as recommended by USGS (2006).
Georegistration onto local coordinates (UTM37S WGS84) was carried out with a $1^{\text {st }}$ degree polynomial adjustment using ArcGIS 9.0 georeferencing tools. The average RMS (root mean square error) for the resulting rectified images was never larger than the suggested threshold of half the original pixel size (30 $\mathrm{m}$ for TM Landsat 5). Original $30 \mathrm{~m}$ pixel size was kept for all subsequent analyses.

Tidal heights for each scene were calculated using the equations in the tide tables of the Hydrographic Institute for the coast of Mozambique (IH, 1994; 2003; 2004), together with the corresponding high- and low-water times (in GMT +2), and levels, and the time of scene capture, available in the documentation files of each scene (in GMT). The reference tide gauges used were Pemba Bay, with correction parameters available for Ibo Island; and Mocímboa da Praia, with correction parameters available for Palma and Vamizi Island (Figure 1). Although the tide level is likely to vary within each scene, given the length of coastline it encompasses (from tens to hundreds of $\mathrm{km}$ ), and computed tides

Table 1: Landsat 5 TM imagery data for 1995 and 2005, including the path/row of the satellite scenes, the date of capture, estimated tidal height in $\mathrm{m}$ above the hydrographic zero (in parentheses), and the reference locations for the tide prediction data. The hydrographic zero for Mocímboa/Palma lies $2.6 \mathrm{~m}$ below mean sea level (MSL), and, for Pemba /Ibo, $2.25 \mathrm{~m}$ below MSL

\begin{tabular}{|c|c|c|c|c|}
\hline Image Area /Tidal height (m) & Path/Row & 1995 & 2005 & Reference \\
\hline Ruvuma (Tanz./Mozamb. Border) & $165 / 067$ & $\begin{array}{l}15.04 .95 \\
(0.87)\end{array}$ & $\begin{array}{l}10.04 .05 \\
(0.93)\end{array}$ & Palma \\
\hline Cabo Delgado & $164 / 067$ & - & $\begin{array}{l}06.08 .04 \\
(2.85)\end{array}$ & Palma \\
\hline Quirimbas Archipelago (North) & $164 / 068$ & $\begin{array}{l}29.07 .95 \\
(1.48-1.71)\end{array}$ & $\begin{array}{l}22.06 .05 \\
(1.01-1.21)\end{array}$ & Mocímboa/Palma/Vamizi \\
\hline Quirimbas (South) to Pemba & $164 / 069$ & $\begin{array}{l}29.07 .95 \\
(1.42)\end{array}$ & $\begin{array}{l}22.06 .05 \\
(0.80)\end{array}$ & Pemba/Ibo \\
\hline
\end{tabular}

GCP's were obtained from data collected with a GPS (Magellan Explorist 100) during field work for habitat ground truthing and from Google Earth (GE) high resolution imagery, available for the entire study area (typically orthorectified Quickbird satellite images with $0.65 \mathrm{~m}$ pixel size). High resolution images from GE allowed us to easily identify landmarks (e.g. roads or coastal features) on Landsat images. Both GPS and GE coordinates were obtained as Lat/Lon (Datum WGS84). could not be corrected for the effects of wind, atmospheric pressure or wave action, predicted tidal heights (Table 1) were used as reference values to aid in the interpretation of the classification results.

Every step of image classification was performed using IDRISI Kilimanjaro vs. 14.02, by Clark Labs, Clark University, (C) 1987-2004. The rectified images were windowed to retain only the relevant working areas (Table 2). Image exploration and 
Table 2: Limits of the working windows extracted from the rectified Landsat 5 TM image data that were used to identify coastal habitats along the Tanzanian and Mozambican coastline. All coordinates are in UTM 37S WGS84

\begin{tabular}{lllllll}
\hline Path/Row & Xmin & Ymin & Xmax & Ymax & COLS & ROWS \\
\hline $165 / 67$ & 616477 & 8776025 & 676507 & 8879705 & 2001 & 3456 \\
$164 / 67$ & 662842 & 8803414 & 685260 & 8842514 & 747 & 1303 \\
$164 / 68$ & 636360 & 8639270 & 691350 & 8829500 & 1833 & 6341 \\
$164 / 69$ & 641195 & 8545080 & 681125 & 8659560 & 1331 & 3816 \\
\hline
\end{tabular}

analysis methodology was first tested in a smaller window, encompassing Pemba Bay. Image striping, a systematic noise due to the TM detector going out of adjustment with time, was deemed to have a possible effect on the results of the classification process and an attempt was made to remove this phenomenon. Since the images acquired from the distributor were already map oriented, an automatic process such as IDRISI's module DESTRIPE could not be used for that radiometric correction. An unstandardized Principal Components Analysis (PCA) was run on the input bands. Components 5, 6 , and 7 , representing less than $1 \%$ of variability (where the variability corresponding to striping tends to be held) were dropped and the original spectral bands were recombined through an inverse PCA based on the first four component images (Eastman, 2003). The result was not fully satisfactory since the bands thus restored still showed evident striping (in fact, even the first principal component exhibited striping) and there appeared to be a loss of radiometric resolution as a result of the process. The recombined bands were thus discarded and classification was performed on the original bands.

In view of the relative uncertainty of currently available algorithms (Giri et al., 2007), no atmospheric corrections were applied to the images since, for the purpose of classification, the priority was to uncover major land cover classes present in each image. As a consequence, the habitat spectra derived from this analysis only apply to the images from which they were extracted (Edwards, 2000). Supervised classification processes require the definition of training sites corresponding to each of the clusters to identify, at an early stage implying a priori knowledge of the study area. This was, however, not the case and therefore classification was performed using an unsupervised classification procedure to "uncover the major land cover classes that exist in the image without prior knowledge to what they might be" (Eastman, 2003). This was based only on their spectral response uniqueness/ specificity. Two different classifiers available in IDRISI Kilimanjaro were tested viz. CLUSTER, a variant of a histogram peak cluster analysis technique (Richards, 1993, in Eastman, 2003), and ISOCLUST, similar to the ISODATA cluster routine of Ball and Hall (1965, in Eastman, 2003). In both cases, it is up to the analyst to identify which of the resulting clusters correspond to a given ground unit, or if a single cluster corresponds to a single ground unit. To retrieve the full array of coastal habitats - terrestrial, intertidal, and subtidal - best results were achieved by applying the ISOCLUST classifier to all seven bands, including the thermal band (Leak and Venugopal, 1990; Alavi Panah and Ehsani, 2004), with five iterations.

This methodology was used in every windowed image, producing 40-65 clusters per working area. All clusters corresponding to terrestrial habitats (roughly $50 \%$ to $66 \%$ of the total) were merged into one class, and so were clusters corresponding to deep marine water and to clouds and cloudcovered areas, where no terrain information was available. In both cases - marine water and clouds - usually one to two clusters were merged. All other clusters inside the target area (c. 16-30) were individually reassigned, to the best of the analyst's ability, to one of eight coastal habitats: permanent shallow marine water, estuarine water, intertidal flats, sand, mangrove, supratidal bare flats, coral reefs, and marine subtidal aquatic beds (algae and/ or seagrass). The selected habitats (Table 3 ) were based upon the Ramsar Classification System for Wetland Type (Ramsar Convention on Wetlands Website, 2007). 
Table 3: Land cover classes/Habitat classification as used for the present paper (the capital letters in parentheses refer to the corresponding Ramsar Wetland Type, where appropriate) (Ramsar Convention on Wetlands Website, 2007)

\begin{tabular}{ll}
\hline Habitats & Notes \\
\hline Marine water & Deep water \\
Permanent shallow marine water & Usually less than 6 meters at low tide includes sea bays and straits (A) \\
Estuarine waters & Turbid waters and permanent water of estuaries and estuarine systems (F) \\
Intertidal flats & Intertidal mud or sand flats (G) \\
Sand & includes sand bars, spits and sandy islets; also includes dune systems (E) \\
Mangrove & (I) \\
Supratidal bareflat & Mostly unvegetated/barren area located between the landward margin of \\
& the mangrove forests and the beginning of terrestrial vegetation. It constitutes \\
& the upper limit of maximum high-water spring tides. Includes sandy, muddy, \\
& and salty sediments \\
Geomorphological classification (rather than an ecological one): includes \\
foral reefs
\end{tabular}

The classified working windows were concatenated to build the mosaics for each year studied: 1995 and 2005. No contextual editing was performed on the images.

Two ground truthing field excursions were undertaken to locations within the study area: Ulo, Mocímboa, Luchete, and Ibo-Tandanhangue in July 2006, and the area in and around Pemba Bay in September 2006. A hand-held GPS was used to collect ground control points (GCPs) (Magellan, Explorist 100). This instrument has a reported accuracy of between 3-30 m, depending on the satellites available and on the presence of physical obstacles such as land relief or tall vegetation (Magellan, 2007). For each location, a descriptive and photographic record was made. A total of 164 GCPs were collected throughout the visited area (Figure 1).

Overall map (user) accuracy and Tau coefficient were estimated for the 2005 mosaic according to Mumby and Green (2000a), with the information available from the field excursions, taken as indicative of major habitats.

\section{RESULTS}

The maps of coastal habitats throughout the study area in 1995 and 2005 are shown in Figure 2. Coverage of each habitat type for 1995 and
2005, and percent change between both years are presented in Table 4 and the overall differences between the two dates are graphed in Figure 3. The area covered by the eight coastal habitats considered varied from $3,660 \mathrm{~km}^{2}$ in 1995 to 3,300 $\mathrm{km}^{2}$ in 2005.

For 1995, the predicted tidal height in the target area was 1.4 to $1.7 \mathrm{~m}$, whereas in 2005 it ranged from 0.8 to $1.2 \mathrm{~m}$, which corresponds to a tide level approximately $0.5 \mathrm{~m}$ lower in 2005 .

The largest class found corresponded to shallow marine water, covering over $1,500 \mathrm{~km}^{2}$, about half the total area classified as coastal habitats. This is also the class where a greater difference between 1995 and 2005 was observed. Intertidal flats were the second largest class, covering about $20 \%$ of the area classified $\left(650-700 \mathrm{~km}^{2}\right)$. This class is directly determined by tidal height and differences between 1995 and 2005 are clearly visible throughout the Quirimbas archipelago onwards to Pemba Bay. Mangroves and coral reefs, each covering about $10 \%$ of the whole area, were the next important classes, each with an area exceeding $300 \mathrm{~km}^{2}$. The remaining four classes in total made up about $10 \%$ of the classified area: ca. $5 \%$ for sandy areas $\left(\sim 130-180 \mathrm{~km}^{2}\right), 2 \%$ each for supratidal bare flats and subtidal aquatic beds $\left(\sim 50-100 \mathrm{~km}^{2}\right)$, and $1 \%$ for estuarine waters (the Ruvuma estuary: 33-46 $\mathrm{km}^{2}$ ). 


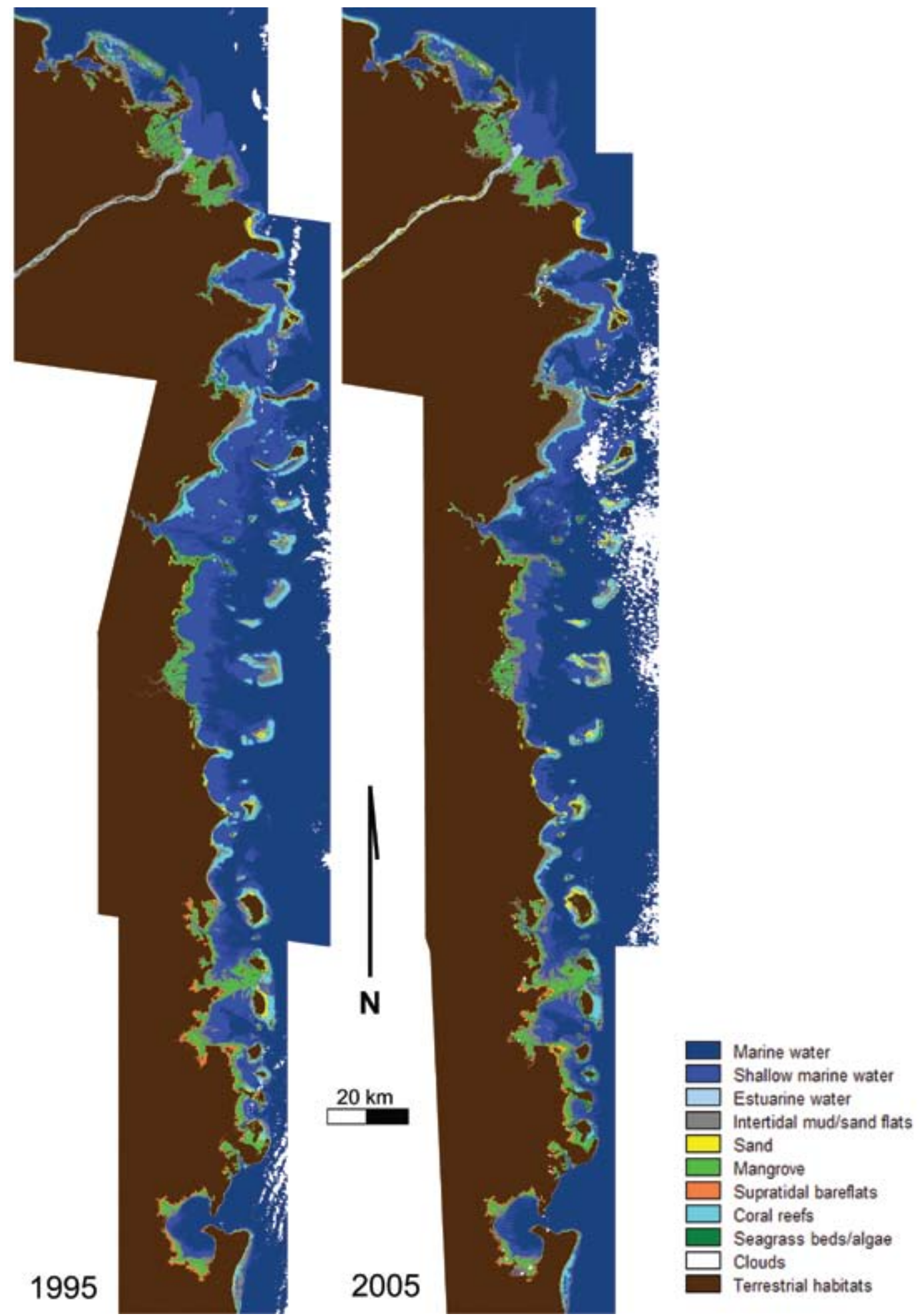

Fig. 2. Distribution of coastal habitats (definitions adapted from the Ramsar Convention Classification System for Wetland Type) throughout the study area. Working windows of Landsat 5 TM scenes were classified using the unsupervised classification algorithm ISOCLUST, prior to mosaicing 
Table 4: Estimated areas (in $\mathbf{~ k m}^{2}$ ) covered by different coastal habitats (adapted from the Ramsar Convention Classification System for Wetland Type) as obtained from the unsupervised classification of Landsat 5 TM imagery pertaining to 1995 and 2005. "Total" refers to the entire study area, from Mnazi Bay (Tanzania) to Pemba Bay (Mozambique), whereas "Ruvuma", "Palma", "Mocímboa" and "Ibo" refer to areas of detail, located throughout the study area (cf. Figure 1). "\%" refers to the percent of change cover between 1995 and 2005

\begin{tabular}{|c|c|c|c|c|c|c|c|c|c|c|c|c|c|c|c|}
\hline \multirow[b]{2}{*}{ Habitat $\left(\mathbf{k m}^{2}\right)$} & \multicolumn{3}{|c|}{ Total } & \multicolumn{2}{|c|}{ Ruvuma } & \multicolumn{4}{|c|}{ Palma } & \multicolumn{2}{|c|}{ Mocímboa } & \multicolumn{4}{|c|}{ Ibo } \\
\hline & 1995 & 2005 & $\%$ & 1995 & 2005 & $\%$ & 1995 & 2005 & $\%$ & 1995 & 2005 & $\%$ & 1995 & 2005 & $\%$ \\
\hline $\begin{array}{l}\text { Permanent shallow } \\
\text { marine water }\end{array}$ & 1907 & 1547 & -19 & 144.2 & 147.8 & 3 & 215.4 & 197.7 & -8 & 263.7 & 153.7 & -42 & 135.3 & 116.6 & -14 \\
\hline Estuarine water & 33 & 46 & 39 & 14.4 & 19.6 & 36 & - & - & & - & - & & - & - & \\
\hline Intertidal flats & 657 & 700 & 7 & 79.5 & 86.9 & 9 & 49.9 & 48.0 & -4 & 21.9 & 59.0 & 169 & 65.0 & 79.1 & 22 \\
\hline Sand & 129 & 178 & 38 & 12.7 & 5.5 & -57 & 11.9 & 16.8 & 41 & 6.6 & 6.6 & 0 & 10.0 & 3.4 & -66 \\
\hline Mangrove & 357 & 368 & 3 & 101.4 & 104.7 & 3 & 7.2 & 10.1 & 40 & 25.5 & 26.4 & 4 & 65.6 & 65.6 & 0 \\
\hline Supratidal bareflat & 83 & 52 & -37 & - & - & & - & - & & - & - & & 19.1 & 17.5 & -8 \\
\hline Coral reefs & 413 & 323 & -22 & 0.4 & 0.0 & -97 & 51.5 & 38.2 & -26 & 18.1 & 11.1 & -39 & 27.0 & 23.2 & -14 \\
\hline $\begin{array}{l}\text { Marine subtidal } \\
\text { aquatic beds }\end{array}$ & 84 & 96 & 14 & 0.3 & 0.3 & 4 & 4.3 & 2.1 & -51 & 16.8 & 11.5 & -31 & 7.7 & 19.6 & 154 \\
\hline
\end{tabular}



Fig. 3. Areas of the classified coastal habitats throughout the study area, for 1995 and 2005

Four smaller areas are presented in detail to allow for comparison between 1995 and 2005 viz. the mouth of the Ruvuma estuary, Palma, Mocímboa and Ibo (see Figure 1 for location and Figure 4 for detailed maps of coastal habitats). The coverage area for the different coastal habitats in these smaller windows and the corresponding percent changes are presented in Table 4. For the mouth the Ruvuma estuary the main differences observed correspond to the extent and the shape of the plume of estuarine water (dependent, among other things, on tidal stage and range, and the amount of river sediment runoff), and the configuration of the intertidal flats adjacent to the mouth, a direct result of coastal geomorphology and dynamics.

Although the area of intertidal flats around Palma looked similar in both years, the width of the areas classified as intertidal areas reflected the $0.5 \mathrm{~m}$ tidal difference at Mocímboa and Ibo. The mangrove area remained virtually unchanged but there were noticeable differences in the areas classified as coral and marine subtidal aquatic beds. The scene encompassing the Ibo area was the only one where the classification process was able to separate supratidal bare flats from other intertidal habitats. 

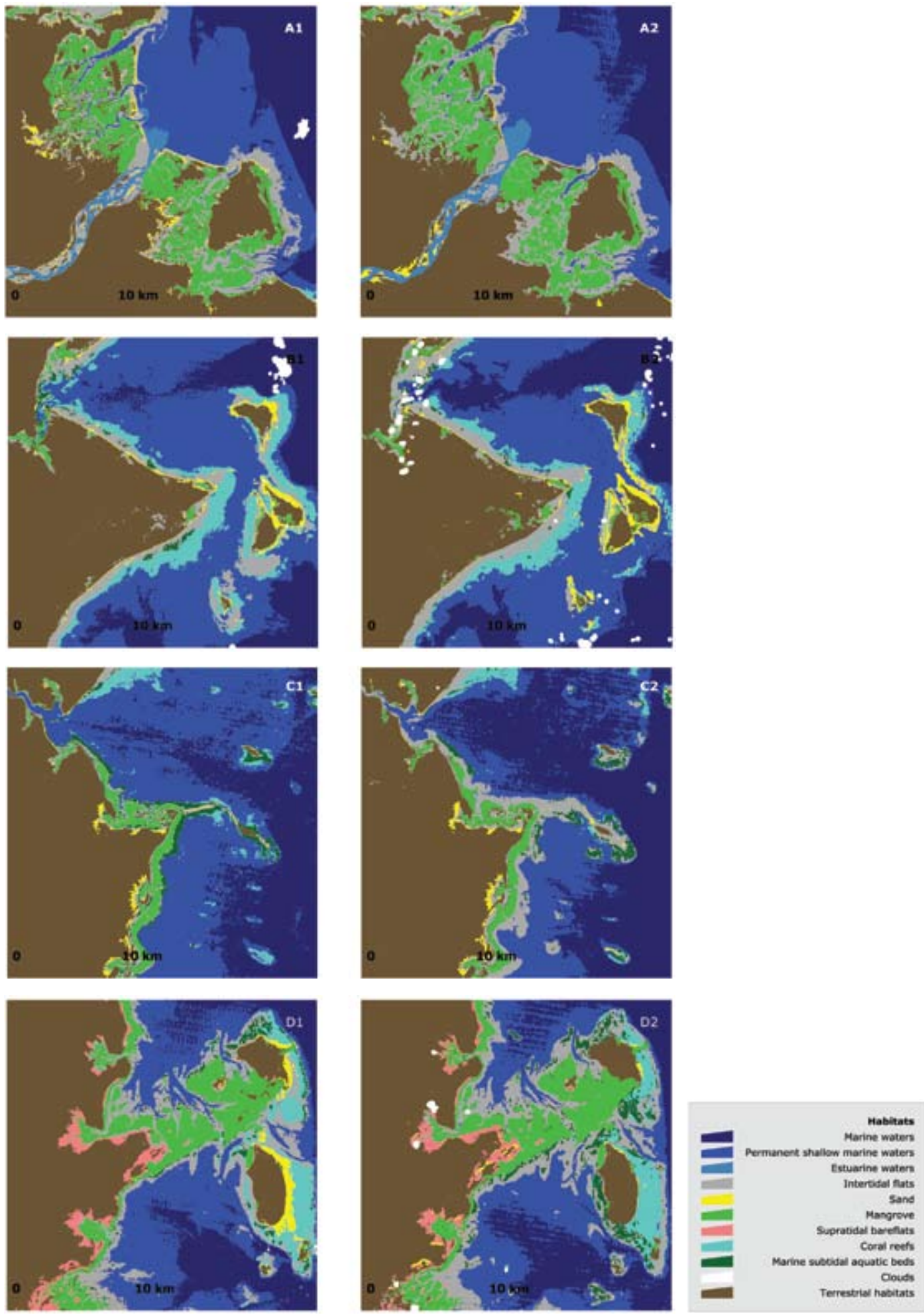

Fig. 4. Detailed view of habitat cover in 1995 and 2005 in four selected areas along the studied coastline (detail of Figure 2). A: Ruvuma estuary (Tanzania/Mozambique border); B: Palma; C: Mocímboa da Praia; and D: Ibo Island (Mozambique) (cf. Figure 1 for location of detail areas). 1: 1995; 2: 2005 
Estimated overall map accuracy and Tau coefficient for the 2005 mosaic were $77 \%$ and $73 \%$ respectively.

\section{DISCUSSION AND CONCLUSION}

Several aspects should be kept in mind when analyzing and comparing the results of the classifications for 1995 and 2005 and also when attempting to assess the classification accuracy. The detection of shallow marine and brackish water habitats and of intertidal flats and sandy beaches can be strongly influenced by extraneous factors such as tide height and range, and weather conditions, all of which influence radiation transmission in the water column.

This is why, despite the importance of the key tropical ecosystems present throughout the study area, mangrove forests, coral reefs and seagrass beds (Dahdouh-Guebas, 2002), in the present case change analysis could only realistically be carried out for mostly emerged habitats, such as mangrove forests. In all other cases, the changes detected integrated, not only actual change in habitat distribution, but also the influence of the above-mentioned uncontrolled factors.

Aspects relating to the classification process, such as classification uncertainty, e.g. during the cluster merging process, or the lack of contextual editing, since classes distribution was solely derived from the classification process, also contributed to the overall uncertainty of the process. Shallow marine water proved to be a problem class because it grouped together clear shallow waters with high bottom reflectance, including coral reefs (e.g. Pemba Bay), and turbid waters, irrespective of their depth (e.g. at the mouth of the Ruvuma estuary), making it dependent on differences in tidal height, tidal stage (flood vs. ebb), and continental runoff. Coral reef extent is likely to have been highly underestimated. This was the habitat with the lowest estimated individual "user accuracy" - c. $40 \%$. Optical remote sensing is limited when it comes to measuring coral reef cover, and is typically only successful in shallow flat reefs (Mumby and Green, $2000 \mathrm{~b})$. This probably relates to the fact that live coral reefs are primarily subtidal. The only parts of the reef which are intertidal are the rocky platforms made up of dead coral, often covered by sediment or vegetation such as algae or seagrass beds, and the reef crest. It is important to mention that a geomorphological classification of the reef was used, rather than an ecological one. In fact, no other approach would have been sensible, or possible, with the present methodology and scale. The determination of live-coral cover is considered the "holy grail" of coral reef remote sensing (ibid.).

Changes in the extent and distribution of habitats such as "sand", "subtidal aquatic beds" and "coral reefs" could reflect, among other things, differences in sediment deposition/erosion, or the natural dynamics of seagrass/algal beds. Moreover, both factors could influence the extent of the area classified as "coral reef" or "intertidal flats".

Mangrove forests, which were probably the best classified habitat, occur throughout the entire coastline and showed an overall estimated increase of 3\% between 1995 and 2005. However, although mangrove cover remained very similar, mangrove condition may have deteriorated. Trends in mangrove cover are discussed in detail in Ferreira et al. (2009).

Quantification of map accuracy was further complicated by a number of sources of uncertainty related to the ground truthing process viz. 1) Scale/ limitations of the ground truthing effort, including remoteness, and inaccessibility of some areas. The number of GCP's necessary to comprehensively cover such a large coastal area would be beyond the financial and time constraints of this project; 2 ) Differences in habitat coverage between the time of scene acquisition and the time of the field excursion (both from natural and anthropogenic causes); 3) Perception of the observer on the field relative to the actual coastal habitat being "sampled"/observed compared to the spectral and spatial resolution of the satellite scene; since for an observer on the ground it may be difficult to identify the dominant land cover, especially when dealing with pixels that correspond to $900 \mathrm{~m}^{2}$ on the ground $-30 \mathrm{~m} \times 30 \mathrm{~m}$, and in the presence of mixed habitats or different ground units (producing mixed pixel signatures, or 'mixels'), or when observing subtidal habitats; 4) Positional errors, resulting from errors in the GPS signal (which can be in the order of a single pixel) and/or in the rectification process, which may result in pixels correctly classified being mapped to locations where other habitats occur. 
Nonetheless, the estimated user (map) accuracy of $>70 \%$ is considered to be satisfactory for the purposes of this study. Mumby and Green (2000a) suggest that "Where habitat maps are used to provide a general inventory of resources as background to a management plan, a thematic accuracy of $60 \%$ is probably as useful as $80 \%$ ".

This paper describes a first attempt to map coastal habitats at a coarse descriptive level and to estimate their areal coverage over $350 \mathrm{~km}$ of coastline along the northern coast of Mozambique and into Tanzania. Both the objectives and the scale of the study do not call or allow for a high detail or resolution, and imply a number of inherent errors. Nonetheless, the estimated overall thematic accuracy of the results makes them a useful tool for conservation planning and management along this coast, and is a reference for future studies. Specifically, the present study may help to identify smaller areas of interest that may now be looked at in greater detail.

The spatially-based data that constitute the base of this study are intended to have the highest possible dissemination among interested researchers and third parties, especially local and regional organizations. The original GIS layers with habitats will be available at the project website (www.transmap.fc.ul.pt) and upon request from the authors. Also the Western Indian Ocean Marine Science Association (WIOMSA) will retain the information, for dissemination purposes, provided any publication acknowledges the TRANSMAP research project and the European Commission as funding agency.

Acknowledgments-This study was part of the TRANSMAP project (contract number INCOCT2004-510862), funded by the $6^{\text {th }}$ Framework Programme of the European Commission.

The Oceanographic Research Institute (ORI), South Africa, was able to source the images at no charge from a South African provider.

The authors gratefully acknowledge the help of Ricardo Nogueira Mendes in revising the manuscript, and the insightful comments of two anonymous referees who greatly helped in focusing the paper and improving its quality.

\section{REFERENCES}

Alavi Panah, S. K. \& Ehsani, A. H. (2004) Monitoring Desertification based on Geographic Information System and Multi-Spectral and Multi-Temporal Satellite Data Case Study; Damghan Playa. Proceedings of the 7 th International Seminar on GIS in developing countries (GISDECO), Malaysia, 10-14 May 2004, 3pp. Cited 23 October 2008. On-line at: http://www.gisdevelopment.net/ proceedings/gisdeco/2004/poster/seyed1.htm

Bandeira, S. O. \& Gell, F. (2003) The seagrasses of Mozambique and southeastern Africa. In: Green, E. P. \& Short, F. T. (eds.). World Atlas of Seagrasses. World Conservation Monitoring Centre. University of California press. p. 105112.

Dahdouh-Guebas, F. (2002) The use of remote sensing and GIS in the sustainable management of tropical coastal ecosystems. Environment, Development and Sustainability 4: 93-112.

Dahdouh-Guebas, F., Coppejans, E. \& Van Speybroeck, D. (1999) Remote sensing and zonation of seagrasses and algae along the Kenyan coast. Hydrobiologia 400: 63-73.

Eastman, J. R. (2003) Idrisi Kilimanjaro: Guide to GIS and Image Processing. Clark Labs, Clark University, Worcester, MA, USA. 328 pp.

Edwards, A. (2000) Guidelines for Busy Decision Makers. In Green, E. P., Mumby, P. J., Edwards, A. J. \& Clark, C. D. (Ed. Edwards, A. J.). Remote Sensing Handbook for Tropical Coastal Management. Coastal Management Sourcebooks 3, UNESCO, Paris. pp. 5-15.

Ferreira, M.A., Andrade, F., Bandeira, S., Cardoso, P., Nogueira Mendes, R. \& Paula, J. (2009) Analysis of cover change (1995-2005) of Tanzania/ Mozambique transboundary mangroves using Landsat imagery. Aquatic Conservation: marine and freshwater ecosystems 19: S38-S45.

Gawler, M. \& Muhando, C. (2004) Development of Mnazi Bay-Ruvuma Estuary Marine Park Midterm Evaluation. FINAL REPORT. UNDP-GEF Project 00015405 - URT/00G31/B/1G/99. Cited 27 September 2009. On-line at: http://cmsdata. iucn.org/downloads/mnazi_bay_mid_term_ review.pdf

Giri, C., Pengra, B., Zhu, Z., Singh, A. \& Tieszen, L. L. (2007) Monitoring mangrove forest dynamics of the Sundarbans in Bangladesh and India using multi-temporal satellite data from 1973 to 2000. Estuarine, Coastal and Shelf Science 73: 91100.

Giri, C., Zhu, Z., Tieszen, L. L., Singh, A., Gillette, S. \& Kelmelis, J.A. (2008) Mangrove forest 
distributions and dynamics (1975-2005) of the tsunami-affected region of Asia. Journal of Biogeography 35: 519-528.

Green, E., Clark, C. \& Edwards A. (2000) Image Classification and Habitat Mapping. In Green, E. P., Mumby, P. J., Edwards, A. J. \& Clark, C. D. (Ed. Edwards, A. J.). Remote Sensing Handbook for Tropical Coastal Management. Coastal Management Sourcebooks 3, UNESCO, Paris. pp. 141-154.

Instituto Hidrográfico $(1994,2003,2004)$ Tabela de Marés 1995, 2004, 2005. Volume II - Países Africanos de Língua Oficial Portuguesa. Instituto Hidrográfico. Marinha. Ministério da Defesa Nacional. Lisboa. 176 pp.

IUCN (2005) Development of the Mnazi Bay Ruvuma Estuary Marine Park. Cited 20 October 2007. On-line at: http://www.iucn.org/places/ earo/prog_links/projects/mnazi.htm.

Leak, S. M. \& Venugopal, G. (1990) Thematic Mapper thermal infrared data in discriminating selected urban features. International Journal of Remote Sensing 11(5): 841-857.

Magellan Navigation (2007) Magellan Explorist 100. Reference Manual. Cited 20 October 2007. On-line at: http://www.magellangps.com/assets/ manuals/eXplorist_100_en.pdf.

Mumby, P. \& Edwards, A. (2000) Remote Sensing Objectives of Coastal Managers. In Green, E. P., Mumby, P. J., Edwards, A. J. \& Clark, C. D. (Ed. Edwards, A. J.). Remote Sensing Handbook for Tropical Coastal Management. Coastal Management Sourcebooks 3, UNESCO, Paris. pp. 31-39.

Mumby, P. \& Green, E. (2000a) Field survey: building the link between image and reality. In Green, E. P., Mumby, P. J., Edwards, A. J. \& Clark, C. D. (Ed. Edwards, A. J.). Remote Sensing Handbook for Tropical Coastal Management. Coastal Management Sourcebooks 3, UNESCO, Paris. pp. 57-65.

Mumby, P. \& Green, E. (2000b) Mapping Coral Reefs and Macroalgae. In Green, E. P., Mumby, P. J., Edwards, A. J. \& Clark, C. D. (Ed.Edwards, A. J.). Remote Sensing Handbook for Tropical Coastal Management. Coastal Management Sourcebooks 3, UNESCO, Paris. pp. 155-174.

Mumby, P. J., Green, E. P., Edwards, A. J. \& Clark, C. D. (1997) Coral reef habitat mapping: how much detail can remote sensing provide? Marine Biology 130: 913-202

Mumby, P. J., Green, E. P., Edwards, A. J., Clark C. D. (1999) The cost-effectiveness of remote sensing for tropical coastal resources assessment and management. Journal of Environmental Management 55(3): 157-166.
Mumby,P., Green,E.,Edwards, A. \& Clark, C. (2000) Cost-effectiveness of Remote Sensing for Coastal Management. In Green, E. P., Mumby, P. J., Edwards, A. J. \& Clark, C. D. (Ed. Edwards, A. J.). Remote Sensing Handbook for Tropical Coastal Management. Coastal Management Sourcebooks 3, UNESCO, Paris. pp. 271-285.

Obura, D., Celliers, L., Machano, H., Mangubhai, S., Mohammed, M., Motta, H., Muhando, C., Muthiga, N., Pereira, M. \& Schleyer, M. (2002) Status of Coral reefs in Eastern Africa: Kenya, Tanzania, Mozambique and South Africa. In: Wilkinson C (ed) Status of Coral Reefs of the World, 2002. Global Coral Reef Monitoring Network (GCRMN). Australian Institute of Marine Science, Townsville, Australia. pp. 63-78.

Obura, D., Church, J., Daniels, C., Kalombo, H., Schleyer, M. \& Suleiman, M. (2004) Status Of Coral Reefs In East Africa 2004: Kenya, Tanzania, Mozambique And South Africa. In: Wilkinson, C. (ed.) Status of coral reefs of the world: 2004. Volume 1. Australian Institute of Marine Science, Townsville, Queensland, Australia. pp. 171-188.

Ochieng, C. A. \& Erftemeijer, P. L. A. (2003) The seagrasses of Kenya and Tanzania. In: Green, E. P. \& Short, F. T. (eds.). World Atlas of Seagrasses. UNEP-WCMC. p 82-92.

Ramsar Convention on Wetlands Website (Ramsar) (2007) The Ramsar Convention classification system for Wetland type. Cited 21 January 2007. On-line at: http://www.ramsar.org/ris/key_ris_ types.htm.

Seto, K. C. \& Fragkias, M. (2007) Mangrove conversion and aquaculture development in Vietnam: A remote sensing-based approach for evaluating the Ramsar Convention on Wetlands. Global Environmental Change 17: 486-500.

Spalding, M. D., Blasco, F. \& Field, C. D., eds. (1997) World Mangrove Atlas. The International Society for Mangrove Ecosystems, Okinawa, Japan. 178 pp.

Spalding, M., Ravilious, C. \& Green, E. (2001) World Atlas of Coral Reefs. UNEP-WCMC. The University of California Press, Berkeley. 424 pp.

Taylor, M., Ravilious, C. \& Green, E. P. (2003) Mangroves of East Africa. UNEP-WCMC Biodiversity Series, no 13. Cambridge. Cited 27 February 2008. On-line at: http://www.gpa.unep. org/documents/mangroves_of_eastern_africa_ english.pdf

Thu, P. M. \& Populus, J. (2007) Status and changes of mangrove forest in Mekong Delta: Case study in Tra Vinh, Vietnam. Estuarine, Coastal and Shelf Science 71: 98-109.

Transmap (2004) Annex I: Description of Work. Unpublished report. 68 pp. Cited 8 November 
2007. On-line at: http://www.nemctan.org/ downloads/eame-transmap.pdf.

United States Geological Survey (USGS) (2006). Thematic Mapper. Product description. U.S. Geological Survey, Earth Resources Observation and Science (EROS). Cited 9 November 2006. On-line at: http://eros.usgs.gov/products/satellite/ tm.html.
Wang, Y., Ngusaru, A., Tobey, J., Makota, V., Bonynge, G., Nugranad, J., Traber, N., Hale, L. \& Bowen, R. (2003) Remote sensing of mangrove change along the Tanzania coast. Marine Geodesy 26: 35-38.

WWF (2002) East Africa Marine Ecoregion Brochure. Cited 20 October 2007. On-line at: http://assets. panda.org/downloads/eamebrochureelectronic. pdf. 
